\title{
Research and Analysis on Market Value Management in China Based on Method of Rank-Sum Ratio and Principal Component Analysis
}

\author{
Yaqian Pan ${ }^{1}$, Wenxin Song ${ }^{2} \&$ Yanjun $\mathrm{Xv}^{2}$ \\ ${ }^{1}$ Finance Department of International Bussiness School, Jinan University, Zhuhai, China \\ ${ }^{2}$ School of Economics, Renmin University of China, Beijing, China \\ Correspondence: Yaqian Pan, Finance Department of International Bussiness School, Jinan University, Qianshan \\ road 206\#, Zhuhai City, Guangdong Province, Post No 519070, China. Tel: 86-158-2058-0592. E-mail: \\ 1710170590@qq.com
}

Received: August 23, 2016

Accepted: September 14, 2016

Online Published: October 25, 2016

doi:10.5539/ijef.v8n11p124

URL: http://dx.doi.org/10.5539/ijef.v8n11p124

\begin{abstract}
Since 2005, China has implemented the split-share reform. After entering the full-circulation era of stock equity, the pursuit for maximize the company value has turned into the primary goal of listed companies in the course of their management and development. Thus, they attach great importance to the concept of market value management. The management of stockholders in listed companies began to pay attention to the inner values and the performances in the stock market of their enterprises, and thereby the concept of market value management is established. However, the weak efficiency of China's capital market has resulted in the deviation between market values and inner values of companies. Thus, companies need to implement market value management and devise corresponding solutions so that two kinds of values can be well-matched.

This paper presents the definition of market value management at first. Next, it studies the background of the emergence of market value management as well as its development status in China, which are also compared with the overseas value management. And then, it makes a literature review and analyzes Economic Value Added Evaluation System (EVA), a performance evaluation system of market value management. It adopts the method of Rank Sum Ratio (RSR)and Principal Component Analysis to make empirical analyses, which evaluates the level of market value management of listed companies in China and discovers the weak links existing in the process of market value management .This paper eventually puts forward corresponding countermeasures and suggestions.
\end{abstract}

Keywords: market value management, EVA evaluation system, RSR method, principal component analysis

\section{Introduction}

\subsection{Definition}

Market value management is a strategic management behavior of listed companies to maximize value creation and optimize value realization on the basis of market value signals and comprehensive applications of various scientific and legal value management methods. It is an important means for listed companies to promote the positive interaction between entity management and capital operation. In regard of market value management, its kernel is value management, which means value creation and realization of shareholder value, and its goal is to pursue sustainable maximum market value of listed companies. The essence of market value management is a long-acting strategic management mechanism.

\subsection{Background}

Market value management is generated in the broad environment where the capital market of China is experiencing a reform. Thus, it possesses distinct Chinese characteristics. However, China's capital market is still in the development stage, exposing many drawbacks of the mechanism and the imperfection of the system. In terms of the studies on market value in our country, it is obvious that theories fall behind practices. Although the theory of market value management has been established for a decade, market value management is still a new thing, of which the problems including meanings, goals, tools and supervision are to be further defined. At present, market value management has not formed a scientific and effective system. Various listed enterprises do not have enough cognition about the relevant theory. Lots of companies have tested the theory. They have taken 
many detours, from which they have also obtained abundant experience. Improving the theory of market value management, especially grasping the overall trend on the macro level, has turned into a problem demanding prompt solution.

Shi Guangyao (2005), a Chinese scholar, has first put forward the definition of market value management. He has pointed out that with the implementation of split-share reform, listed companies are bound to conduct management for the growth of market value, and therefore, they will take three aspects including shareholder benefit, share price and share capital into consideration so as to implement market value management. Zhu Some scholars including Liu Guofang (2007) think that the inner value of listed company is the basis for its market value, and the market value of listed company is the outward manifestation of its inner value, representing the wealth of shareholders and being the goal of market value management. In terms of evaluating the market value management level of a listed company, primarily, it is required to evaluate the company's ability of value creation, and it should also pay attention to the realization of its inner value, i.e. market performance. As for market value management, this paper thinks that it is listed enterprises' pursuit for the coordination and unity between their inner values and market values. Based on the idea of maximizing values, these companies continuously promote the growth of value in different channels including external investment, financing and stock through internal innovation of management and improvement of values.

One of the theoretical bases for the studies on market value management is the management of values, i.e. the management of companies' inner values and market values. The immature capital market of China, to some extent, has also resulted in the low efficiency of companies' market value managements, which have failed to reflect the true inner values of companies. The goal of value management lies in that companies can maximize the shareholder value through value management, which is beneficial to shareholders and various stakeholders. Meanwhile, the companies can also obtain capital for maintaining operation, growth and development. To realize value management, enterprises need not only the operation of finance department but also the full cooperation among all departments of the whole company. Value management requires an overall analysis of the total strategy and operating activities of the company. It also requires to combine the growth target, status analysis and management method of the company so as to realize the core target of maximizing the company value, and to generalize a set of comprehensive management methods.

\subsection{Development Status}

1) Chaotic phenomena frequently occur in the market value management.

2) The understanding of the theories of market value management is unsystematic, and the cognition is deviated.

3) The share incentive mechanism is not perfect, and the consciousness of market value is not strong enough.

4) China's economy steps into the new normal phase. The reform of listed enterprises is imperative.

5) The modes of market value management are distorted.

\subsection{Overseas Situation}

So far, a relatively mature securities market has been formed abroad. The investors are more rational. The market values of the companies are closely related to their inner values, reflected in the high unity between share prices and market values. Therefore, the overseas market do not emphasize the concept of market value management. Instead, the studies on value management are attached with more importance. The theories of value management can date back to Fisher's theory of capital value (1906) at the beginning of the 20th century, followed by some well-known theories including Modigliani-Miller Theorem (M\&M), Mode of Shareholder Value, Value Management (Management Based on Value), etc. All of these theories have promoted the continuous development and improvement of value management theories. Because of the complexity and richness of enterprises' inner values, three enterprise values have been formed from different viewing perspectives, namely, enterprise value based on discounted cash flow, on Tobin Q Value and on EVA. Different from listed companies in China, the western listed companies pay more attention to cash flow and capital. The goal of maximizing values is generally accepted. The system of value management is generally implemented on the basis of efficient market.

\subsection{Literature Review}

One of the theoretical foundations of market value management is the management of value, which includes the management of the intrinsic value and the market value of the company. In China, the capital market is still immature. To a certain extent it has led to the low efficiency of market value management in company and can 
not correctly reflect the size of the intrinsic value of the company. With the gradually progress of capital market value management will be the development trend of market value management, which can provide policy recommendations for Chinese listed companies at the present stage to use the correct market value management strategy. So it is necessary to review the content of value management. As early as 1980s, it appeared in the value management of research activities in the United States. And under the strong promotion of entrepreneurs, a more complete value management system has formed. Arnold (1998) pointed out the view that value management is to maximize the interests of the holders of wealth. It means added value of shareholder to the listed company. The company's strategic development, structural adjustment and performance, culture are all centered on this core objective. KPMG Consulting (1999) pointed out that the value management is a set of management system which is produced by the modern enterprise around how to promote the shareholder value. All the activities of the enterprise will focus on the maximization of shareholder's interests. And it will integrate into the company organization, personnel appointment and management method. Value management is defined from the viewpoint of value creation by Christopher and Ryals (1999). Whether the value of the real value added and the company in the surplus after the deficit, the focus is not simply on the book value.

Chinese scholars Qu Jun Xiang and Yang Ziyan (2003) analyzed the connotation of value management system from the perspective of value management process. They pointed out that it is a set of methods and modes which are widely used in every level of the company. It is to increase the value of the shareholders finally. The company's strategic development, changes in the field of investment, incentive mechanisms, investor relations, etc. are all reflected the core objectives of shareholder value maximization. Liu Guofang (2007) believes that in the western mature capital market, the operating level and the real value of the company will be reflected through the market value. But in the weakly effective capital market, there will always be deviation more or less. The phenomenon will be corrected only when the market becomes standard and mature. Lingchuan (2007) holds the view that the so-called market value management refers to a process as follows: in order to stabilize and improve the market value of companies, listed companies establish a long-acting mechanism to improve their valuation levels. They are dedicated to maximizing the company values to create values for shareholders. All of the management behaviors of listed companies, such as investment, financing, dividend policies and so on, closely center on the core goal of the maximization of long-term, sustainable and healthy market value. Xu Lixia (2012) put forward the view that to realize the maximization of enterprise value is the goal of business combination. She gave the relevant theoretical guidance and put forward the policy recommendations to enhance the efficiency of the combination.

Generally speaking, the goal of value management is to realize the maximization of shareholder value through value management. It not only benefits the shareholders of the company, but also benefits the different stakeholders. At the same time, the company itself can also receive the fund to maintain and develop in the market. Realizing the full value management, company need not only the operation of the financial sector but the full cooperation of the company.

\section{Chinese Performance Evaluation System of Market Value Management}

The principle of Economic Value Added (EVA) generated in the 1990s has made a new try in the evaluation of enterprise value from a higher strategic level. Its outstanding feature is to regard the cost of equity as an opportunity cost. In the course of measuring the value management performance of the enterprise, it takes the earnings after deducting the opportunity cost as the standard to judge whether the enterprise creates values for shareholders or not. Gradually, EVA is becoming more and more popular with a great many research institutions and investment organizations, turning into the most important index for enterprises especially listed companies to evaluate their current situations of value management. 
Table 1. EVA evaluation index system

\begin{tabular}{|c|c|c|c|c|c|c|}
\hline $\begin{array}{l}\text { First-grade } \\
\text { Indicator }\end{array}$ & Weight & $\begin{array}{l}\text { Second-grade } \\
\text { Indicator }\end{array}$ & Weight & $\begin{array}{l}\text { Third-grade } \\
\text { Indicator }\end{array}$ & Weight & Definition of Indicator \\
\hline \multirow[t]{9}{*}{$\begin{array}{l}\text { Value Creation } \\
\qquad(\mathrm{VC})\end{array}$} & $30 \%$ & $\begin{array}{l}\text { Ability of } \\
\text { Value }\end{array}$ & $50 \%$ & EVA & $20 \%$ & $\begin{array}{l}\text { Economic value added of the enterprise during a } \\
\text { period }\end{array}$ \\
\hline & & Creation & & Capital Efficiency & $20 \%$ & Operating efficiency of the enterprise's capital \\
\hline & & & & $\begin{array}{c}\text { Earnings Ratio of } \\
\text { Main Business }\end{array}$ & $20 \%$ & Profit level of the enterprise's main business \\
\hline & & & & $\begin{array}{l}\text { Earnings Ratio of } \\
\text { Net Assets }\end{array}$ & $20 \%$ & Profit level of the enterprise's owned capital \\
\hline & & & & EPS & $20 \%$ & Earnings per share \\
\hline & & $\begin{array}{l}\text { Growth of } \\
\text { Value }\end{array}$ & $50 \%$ & $\begin{array}{c}\text { Growth Rate of } \\
\text { EVA }\end{array}$ & $20 \%$ & Growth of capital efficiency \\
\hline & & Creation & & $\begin{array}{l}\text { Earnings Ratio of } \\
\text { Main Business }\end{array}$ & $20 \%$ & Growth of earning ratio of main business \\
\hline & & & & $\begin{array}{l}\text { Earnings Ratio of } \\
\text { Net Assets }\end{array}$ & $20 \%$ & Growth of profit level of owned capital \\
\hline & & & & $\begin{array}{l}\text { Growth Rate of } \\
\text { EPS }\end{array}$ & $20 \%$ & Growth of earnings per share of the enterprise \\
\hline \multirow{6}{*}{$\begin{array}{l}\text { Value Realization } \\
\text { (VR) }\end{array}$} & $50 \%$ & Aggregate & $60 \%$ & MA & $40 \%$ & Scale of the enterprise's overall market value \\
\hline & & $\begin{array}{l}\text { Market Value } \\
\text { (MA) }\end{array}$ & & $\begin{array}{c}\text { Growth Rate of } \\
\text { MA }\end{array}$ & $40 \%$ & Growth of the enterprise's market value \\
\hline & & & & Tobin Q & $20 \%$ & $\begin{array}{l}\text { When } Q>1 \text { and the company value is higher } \\
\text { than the replacement cost, the higher } Q \text { value is, } \\
\text { the better the performance of market value will } \\
\text { be. }\end{array}$ \\
\hline & & Market Value & $40 \%$ & MVA & $40 \%$ & Value added of the enterprise's wealth \\
\hline & & $\begin{array}{l}\text { Added } \\
\text { (MVA) }\end{array}$ & & $\begin{array}{c}\text { Growth Rate of } \\
\text { MVA }\end{array}$ & $40 \%$ & Growth of value added of the wealth \\
\hline & & & & Rate of MVA & $20 \%$ & The wealth created by unit cost of the enterprise \\
\hline Value Correlation & $20 \%$ & & & & & \\
\hline
\end{tabular}

\section{Empirical Analysis of Market Value Management and Empirical Results}

\subsection{Selection of Financial Index}

Centering on market value of company, this paper selects 8 financial index closely related to the market value of listed companies as shown in the following Table 2.

Table 2. Explanatory factor

\begin{tabular}{lcc}
\hline Classification & Explanatory Factor & Factor Code \\
\hline Index Reflecting Profitability & Return on Equity (ROE) & $\mathrm{X}_{1}$ \\
Index Reflecting Debt Paying Ability & Equity Ratio (the Lower the Better) & $\mathrm{X}_{2}$ \\
Index Reflecting Growth Ability & Growth of Primary Earnings Per Share & $\mathrm{X}_{3}$ \\
Index Reflecting the Ability of Capital Management & Total Assets Turnover & $\mathrm{X}_{4}$ \\
Index Reflecting Revenue Quality Ability & Net Earnings of Operating Activities / Total Profit & $\mathrm{X}_{5}$ \\
Index Reflecting Profit-sharing Ability & Balance of Cash and Cash Equivalents Per Share & $\mathrm{X}_{6}$ \\
Index Reflecting the Standard to Measure Share Price after & Tobin Q Value & $\mathrm{X}_{7}$ \\
Eliminating Size Factors & & $\mathrm{X}_{8}$ \\
Index Reflecting the Scale of Shareholder Value & Market Value of the Company & $\mathrm{X}_{9}$ \\
Index Reflecting Investment Value & P/B Ratio (the Lower, the Better) & \\
\hline
\end{tabular}

Among the indexes above, Return on Equity, also named Return on Shareholders' Equity, is an important index which reflects the profitability of listed companies. The higher the index value is, the more earnings the investment brings. Equity Ratio is the ratio between total liabilities and total owner's equity. It refers to the ratio between total shareholders' equity and total enterprise assets of corporate enterprises, and it is an index for 
evaluating the rationality of capital structure. As one of the indexes to measure the long-term solvency of the enterprise, this ratio is an important signal to indicate whether the enterprise's financial structure is steady or not. The higher the equity ratio is, the weaker the long-term solvency is, and the lower the equity ratio is, the stronger the long-term solvency is. Total Assets Turnover is the ratio between net revenue of business and total average assets during a period. This ratio is an important index to inspect the operational efficiency of enterprise assets. Generally, the higher the ratio is, the quicker the turnover velocity of total assets is. The stronger the marketing ability is, the higher the utilization efficiency of assets is. Indeed, Tobin Q Value is an estimation of the assets value and the cost to produce these assets of the enterprise, and it is calculated by the stock market. Faced with high Q value, the enterprise will choose to transform financial capital into industrial capital later. And when the $\mathrm{Q}$ value is low, the enterprise will transform industrial capital into financial capital, which means continuing to hold the shares or choosing to hold more shares. P/B Ratio is the ratio between stock price per share and net asset value per share. It can be used in investment analysis. Generally speaking, the stocks of lower P/B Ratio have higher investment values.

\subsection{Data Source}

The major data sources of this paper is the website of China Financial Information (http://cfi.cn/). The paper selects the data of financial indexes of 30 listed companies in 19 industries and the public data on the annual reports of the listed companies.

\subsection{Data Pre-Cleaning}

Data pre-cleaning is an important step before model building. It mainly includes the verification of data validity and the normalization of the data.

The data of the financial index variables in the model study of this paper have experienced a long time span. They have also a wide range and various categorizations. The data come from different financial databases, financial regulators and industry associations. Thus, they might have different statistical calibers. Some data might be lost or even obviously inconsistent with the facts. In such circumstances, this paper adopts the method of linear interpolation to make up the missing data so as to ensure the consistency and validity of the data.

After processing the missing data and the data inconsistent with the facts, the data of each index might be inconsistent in dimension. In order to unify the dimensions of regression variables, the paper conducts normalization of the data. The methods frequently used for normalization include normalizations of range, of standard deviation and of exponent. According to the features of the data acquired by the paper, it selects Z-score normalization, turning each variable into standard variable obeying normal distribution.

\subsection{Rank-Sum Ratio}

Rank-sum ratio (RSR) is a set of methods for statistical analysis. As a comprehensive index of rich meaning, RSR is characterized by continuous variables from 0 to 1 . RSR takes nonparametric statistical method as its basis, conducts transformation of ranks through index number (column) and group number (row), and then makes an analysis of the distribution of RSR through the application of the concept and method of parameter analysis. Thus, it can resolve the multi-index evaluation.

Firstly, it should code ranks for each index involved in the evaluation. As for indexes which are better when they are higher, they should be coded from small to large, and for indexes which are better when they are lower, they should be coded from large to small. When the ranks of some indexes are the same, take the average of these index values. In this paper, P/B Ratio and Equity Ratio are two indexes which are better when they are lower. Part of the results of rank coding are shown in Table 3.

Table 3. The results of rank coding

\begin{tabular}{lccccccc}
\hline Stock Code & 000001 & 000040 & 000413 & 000636 & 000677 & 000835 & 000851 \\
\hline $\mathrm{X}_{1}$ & 0.47 & 2.22 & 0.04 & 0.35 & -0.18 & -0.27 & 0.48 \\
& 21 & 29 & 14 & 19 & 9 & 8 & 22 \\
$\mathrm{X}_{7}$ & -0.15 & 5.18 & 0.05 & -0.18 & -0.23 & -0.26 & -0.17 \\
& 24 & 29 & 28 & 19 & 8 & 4 & 20 \\
$\mathrm{X}_{8}$ & -0.39 & -0.39 & -0.42 & -0.40 & -0.44 & -0.30 & -0.33 \\
& 11 & 12 & 7 & 10 & 4 & 19 & 15 \\
$\mathrm{X}_{9}$ & -0.14 & 5.19 & 0.06 & -0.20 & -0.23 & -0.26 & -0.19 \\
& 7 & 1 & 2 & 15 & 22 & 26 & 14 \\
\hline
\end{tabular}


Secondly, calculate RSR of each index according to the formula.

$$
R S R_{i}=\frac{\sum_{j=1}^{m} R_{i j}}{n * m}
$$

In the formula above, $m$ refers to the number of indexes, and $n$ represents the number of groups. $R_{i}$ is the rank of each index. The value of RSR is exactly the average rank of multiple indexes, which is better when the value is higher. If the weight of each index is not the same, calculate the Weighted RSR (WRSR) according to the following formula:

$$
W R S R_{i}=\frac{1}{n} \sum_{j=1}^{m} W_{j} R_{i j}
$$

In the formula above, $R_{i j}$ is the rank of the index value in row $i$ and column $j$. Part of the calculation results of RSR are shown in Table 4.

Table 4. The calculation results of RSR

\begin{tabular}{lcccc}
\hline Stock Code & RSR & $\mathrm{R} / \mathrm{n}$ & Y Probability & Grade \\
\hline 000001 & 0.56 & 0.66 & 5.40 & Good \\
000040 & 0.42 & 0.24 & 4.30 & Alert \\
000413 & 0.54 & 0.55 & 5.13 & Good \\
000636 & 0.52 & 0.48 & 4.96 & Alert \\
000677 & 0.40 & 0.14 & 3.91 & Alert \\
002115 & 0.69 & 0.99 & 7.38 & Excellent \\
\hline
\end{tabular}

Thirdly, determine the distribution of RSR.

Conduct normality test of RSR value. When the result of Shapiro-Wilk significance test is larger than 0.05 , it accords with the explanation of normal distribution.

Table 5. Normality test

\begin{tabular}{ccccccc}
\hline & \multicolumn{3}{c}{ Kolmogorov-Smirnov } & & Shapiro-Wilk \\
\hline \multirow{2}{*}{ RSR } & Statistical Data & $\mathrm{df}$ & Significance & Statistical Data & df & Significance \\
& .101 & 29 & .200 & .958 & 29 & .301 \\
\hline
\end{tabular}

Fourthly, solve the regression equation: take $\mathrm{Y}$, the value of probability unit corresponding to the accumulative frequency, as the independent variable, and take the value of RSR as the dependent variable. Then, calculate the regression equation $-0.04+0.11 \mathrm{y}=\mathrm{RSR}$. According to the table of regression analysis results, we can see that when R Square is larger than 0.9 , the fitting degree is better. F-value is 1257 , and P-value is 6.71E-23, smaller than 0.05 . Thus, it indicates that the regression equation has statistical significance.

Table 6. Variance analysis

\begin{tabular}{lccccccc}
\hline & df & SS & MS & F & Significance F & R Square & Adjusted R Square \\
\hline Regression Analysis & 1 & 0.32 & 0.32 & 359.65 & $9.52 \mathrm{E}-17$ & 0.93 & 0.93 \\
Residual & 26 & 0.02 & 0.00 & & & & \\
Total & 27 & 0.35 & & & & & \\
\hline
\end{tabular}

Table 7. Coefficient analysis

\begin{tabular}{lcccccc}
\hline & Coefficients & Standard Error & $\mathrm{t}$ Stat & P-value & Lower 95\% & Upper 95\% \\
\hline Intercept & -0.04 & 0.03 & -1.39 & 0.18 & -0.10 & 0.02 \\
$\mathrm{Y}$ & 0.11 & 0.01 & 18.96 & 0.00 & 0.10 & 0.12 \\
\hline
\end{tabular}

Fifthly, sort and classify the listed companies according to RSR values. On the basis of rational classified numerical tables, the evaluation objects are classified and ordered according to RSR values. The paper classified the listed companies into four grades, namely, excellent, good, alert, and required to adjust. 
The meaning of the best classification and order is that the variances in each classification are consistent, and the discrepancies are significant. At first, conduct the consistency test of variances. If all the variances in the group of homogeneity test of variance in the table are no more than 0.20 , it indicates that the variances in each classification are consistent. According to the intergroup variance analysis, we can see that $\mathrm{F}=37.26$ and $\mathrm{P}=0.00$, indicating that there are significant differences among these classifications. Thereby, the best classification is realized.

Table 8. Variance analysis: Single-factor analysis

\begin{tabular}{|c|c|c|c|c|c|c|}
\hline Group & Nun & ation & Sum & Average & \multicolumn{2}{|c|}{ Variance } \\
\hline Column 1 & \multicolumn{2}{|c|}{1} & 3.18 & 3.18 & \multicolumn{2}{|c|}{0} \\
\hline Column 2 & \multicolumn{2}{|c|}{13} & 56.52 & 4.35 & \multicolumn{2}{|c|}{0.20} \\
\hline Column 3 & \multicolumn{2}{|c|}{12} & 67.39 & 5.62 & \multicolumn{2}{|c|}{0.20} \\
\hline Column 4 & \multicolumn{2}{|c|}{2} & 14.2 & 7.1 & \multicolumn{2}{|c|}{0.16} \\
\hline Source of Variance & SS & $\mathrm{df}$ & MS & $\mathrm{F}$ & $\mathrm{P}$-value & F crit \\
\hline Intergroup & 22.16 & 3 & 7.39 & 37.26 & 0.00 & 3.01 \\
\hline Intragroup & 4.76 & 24 & 0.20 & & & \\
\hline
\end{tabular}

The RSR method can collect the relevant financial indexes of listed companies. Centering on the issue of market value, it grades the situations of companies' market value management, helping the listed companies adjust their managements of inner values timely according to the grade. Therefore, they can reach a unity between inner value and external market value. The operation of this model is simple and useful, so it is worth promoting.

\subsection{Principal Component Analysis}

Due to there is a certain correlation among the 9 indexes of listed companies, there is a strong information overlap among variables. If the data were analyzed directly, the workload will be increased and there will be some errors in the application of the model. The article chooses the method of the principal component analysis. On the premise of not losing a large amount of information, use fewer independent variables to replace the original variables for further analysis. Firstly, the correlation analysis of the 9 variables which has been standardized is carried out as Table 9.

Table 9. Correlation matrix

\begin{tabular}{cccccccccc}
\hline & $\mathrm{X}_{8}$ & $\mathrm{X}_{9}$ & $\mathrm{X}_{7}$ & $\mathrm{X}_{1}$ & $\mathrm{X}_{2}$ & $\mathrm{X}_{3}$ & $\mathrm{X}_{4}$ & $\mathrm{X}_{5}$ & $\mathrm{X}_{6}$ \\
\hline $\mathrm{X}_{8}$ & 1.00 & -0.11 & -0.11 & 0.34 & 0.89 & -0.03 & -0.20 & 0.50 & 0.85 \\
$\mathrm{X}_{9}$ & -0.11 & 1.00 & 1.00 & 0.42 & -0.09 & -0.11 & 0.91 & 0.02 & -0.12 \\
$\mathrm{X}_{7}$ & -0.11 & 1.00 & 1.00 & 0.42 & -0.09 & -0.11 & 0.92 & 0.02 & -0.12 \\
$\mathrm{X}_{1}$ & 0.34 & 0.42 & 0.42 & 1.00 & 0.23 & 0.34 & 0.54 & 0.36 & 0.28 \\
$\mathrm{X}_{2}$ & 0.89 & -0.09 & -0.09 & 0.23 & 1.00 & 0.00 & -0.16 & 0.52 & 0.92 \\
$\mathrm{X}_{3}$ & -0.03 & -0.11 & -0.11 & 0.34 & 0.00 & 1.00 & -0.05 & 0.03 & 0.00 \\
$\mathrm{X}_{4}$ & -0.20 & 0.91 & 0.92 & 0.54 & -0.16 & -0.05 & 1.00 & 0.10 & -0.21 \\
$\mathrm{X}_{5}$ & 0.50 & 0.02 & 0.02 & 0.36 & 0.52 & 0.03 & 0.10 & 1.00 & 0.36 \\
$\mathrm{X}_{6}$ & 0.85 & -0.12 & -0.12 & 0.28 & 0.92 & 0.00 & -0.21 & 0.36 & 1.00 \\
\hline
\end{tabular}

Table 9 indicates that there is a certain correlation among the variables and the correlation coefficient among some variables is still relatively large. For example correlation coefficient among variable $\mathrm{X}_{8}$ and $\mathrm{X}_{7}, \mathrm{X}_{2}$ and $\mathrm{X}_{9}$, $\mathrm{X}_{9}$ and $\mathrm{X}_{4}$ are close to 1 .It indicates that the 9 variable are suitable for he method of the principal component analysis. 
Table 10. Variance contribution rate and accumulative proportion in ANOVA

\begin{tabular}{lccccc}
\hline component & \multicolumn{3}{c}{ Initial eigenvalue } & \multicolumn{2}{c}{ Sum of squares } \\
\hline 1 & Grand total & Variance $\%$ & Total sum $\%$ & Grand total & Variance $\%$ \\
& 3.35 & 37.24 & 37.24 & 3.35 & 37.24 \\
2 & 3.11 & 34.56 & 71.80 & 3.11 & 34.56 \\
3 & 1.22 & 13.51 & 85.31 & 1.22 & \\
5 & 0.70 & 7.76 & 93.07 & & \\
6 & 0.38 & 4.18 & 97.24 & \\
7 & 0.15 & 1.67 & 98.92 & \\
8 & 0.07 & 0.83 & 99.75 & \\
9 & 0.02 & 0.25 & 100.00 & & \\
\hline
\end{tabular}

The Table 10 shows us that the eigenvalue of the first three components is greater than 1 , So the contribution rate of the first principal component of the first three principal components is $37.24 \%$, the second PC contribution rate is $34.56 \%$. The cumulative contribution rate of the three principal components was $85.31 \%$, which is enough to replace the original variable. These components cover almost all the information of the original variable.

Table 11. Component matrix

\begin{tabular}{cccccccccc}
\hline & $\mathrm{X}_{8}$ & $\mathrm{X}_{9}$ & $\mathrm{X}_{7}$ & $\mathrm{X}_{1}$ & $\mathrm{X}_{2}$ & $\mathrm{X}_{3}$ & $\mathrm{X}_{4}$ & $\mathrm{X}_{5}$ & $\mathrm{X}_{6}$ \\
\hline 1 & 0.76 & -0.68 & -0.68 & -0.06 & 0.77 & 0.06 & -0.71 & 0.40 & 0.76 \\
2 & 0.55 & 0.69 & 0.69 & 0.76 & 0.56 & 0.04 & 0.66 & 0.53 & 0.51 \\
3 & -0.11 & -0.16 & -0.16 & 0.47 & -0.15 & 0.94 & -0.01 & 0.08 & -0.12 \\
\hline
\end{tabular}

Table gives the coefficient matrix between the principal components and the standardized form of the variables. The load of each principal component on each variable is indicated.

$$
\begin{gathered}
F_{1}=0.76 X_{8}-0.68 X_{9}-0.68 X_{7}-0.06 X_{1}+0.77 X_{2}+0.06 X_{3}-0.71 X_{4}+0.4 X_{5}+0.76 X_{6} \\
F_{2}=0.55 X_{8}+0.69 X_{9}+0.69 X_{7}+0.76 X_{1}+0.56 X_{2}+0.04 X_{3}+0.66 X_{4}+0.53 X_{5}+0.51 X_{6} \\
F_{3}=-0.11 X_{8}-0.16 X_{9}-0.16 X_{7}+0.47 X_{1}-0.15 X_{2}+0.94 X_{3}-0.01 X_{4}+0.08 X_{5}-0.12 X_{6}
\end{gathered}
$$

The Table 11 shows that in the first principal component, the coefficient of $X_{2}, X_{6}, X_{8}$ is large, which can be seen as the comprehensive indicators of solvency, dividend capacity and market value. In the second principal component, the coefficient of $X_{1}, X_{7}, X_{9}$ is large, which can be seen as the comprehensive indicators of profitability, investment returns and investment value. In the third principal component, the coefficient of $X_{3}$ is large, which can be seen as the comprehensive indicators of growth ability. Different listed companies can be different which is divided by the general strategy of the company, giving different weights to the three principal components. In this paper, the company's growth and profitability are the main target. The weights of the three principal components are $0.5,0.3$ and 0.2 and the total score formula is obtained.

$$
Y=0.5 F_{1}+0.3 F_{2}+0.2 F_{3}
$$

The comprehensive ability of a listed company can be measured by the total score formula and can also forecast the future development. Based on the changes of indicators timely analysis the terms the listed companies need to adjust. Guide the next step of the development of the company.

\section{Conclusion and Recommendations}

\subsection{Macro Perspective}

The government and regulators should strengthen the macro control of the stock market. Faced with the current fluctuation in the stock market, the government and regulators should introduce corresponding measures to stabilize the market, among which the measures directly related to the market value managements of listed companies include forbidding top managers to unload their shares during a certain period, encouraging them to hold more shares, allowing China Securities Finance Corporation Limited and Central Huijin Investment Ltd. to enter the market directly and buy shares so as to stabilize share prices, etc.

Encourage listed companies to establish systems of market value management. Strengthen the external constraint to lead listed companies to adhere to the principle of maximizing the shareholder value. Listed companies should 
improve their administration levels and increase the transparency of information disclosure. They should also actively intervene in the share prices of their companies through ways such as increasing the shares held by managers, repurchasing the shares and so on, so that the share prices can reflect the inner values of companies more accurately. Perfect and standardize the system. The relevant regulators should also take further measures so as to standardize and ensure the smooth proceeding of listed companies' establishment of the systems of market value management. Encourage them to explore the market value management with Chinese characteristics.

Further reinforce the information disclosure of listed companies and intensify the comprehensive comparison, screening and analysis of unusual transactions. Regulators should dig deep into the clues of market manipulation. They should timely bring the relevant cases meeting the conditions into special operations of law enforcement, and intensify the forces against illegal phenomena so as to maintain the market order and protect the interest of medium and small investors. Improving the fiduciary duty consciousness of shareholders of listed companies is an important part of the equity culture of a mature market.

\subsection{Micro Perspective}

Listed companies should determine the goal of market value management at first, namely, to realize the maximization and optimization of value creation and enable the share prices to reflect the inner values of companies more accurately. Listed companies should make full preparation for the industrial transformation. They should endeavor to dig out their own values, and have in-depth development in the industry or create new business models. The effective combination between technological innovation and Internet thinking is a powerful tool to realize the developments of companies. By virtue of Internet or financial platforms on the Internet, listed companies can realize the transformation of themselves and the industrial chain.

Listed companies should lay emphasis on improving the ability and performance of value creation, and pay attention to optimizing the key factors influencing market values. On one hand, listed companies can make themselves bigger and stronger through extension development. On the other hand, they can improve the market evaluation through merger and acquisition. Therefore, they can effectively improve the performance of market value management.

Listed companies should do well in the emergency management and risk prevention measures during the crisis period.

As for emergency management, listed companies should do well in the investor relations management, the purpose of which is to promote the mutual understanding and trust between investors and listed companies, and encourage investors to hold long-term shares. Thus, it is helpful to stabilize share prices and reduce unusual fluctuations. In the situation where the fluctuation of market is relatively drastic, listed companies should approach investors more actively. They can help investors get to know more about the fundamentals through various interaction forms such as performance illustration meetings, on-site survey and online roadshows, so that they can improve investors' confidence to hold long-term shares.

As for risk prevention measures, listed companies can reduce the impact of systematic risks through cross listing. Particularly, when some systematic risk events take place in some regions, it is almost impossible for listed companies to eliminate negative impacts completely. If the stocks of listed companies are traded in different markets at the same time, and these market have little relevance, the share prices of the stocks of listed companies in other markets can help them stabilize their shares prices in Chinese market.

\section{Limitations and Expectations of the Study}

\subsection{Limitations of the Study}

When it measures the values created by listed companies for shareholders through RSR method, it adopts simplified calculating method because of the large samples of companies, and it overlooks non-critical factors of EVA. Therefore, the calculation results may not be accurate enough.

In the selection of indexes to evaluate the value management abilities of listed companies, because the process involves many aspects including financial affairs, customers, investors and corporate internal governance, the study only takes the core factors of value creation as the selection principle and overlooks the non-critical factors of value creation. Therefore, the indexes for evaluation are not comprehensive enough.

Currently, the exploitation and promotion of market value management is still difficult. As the coverage of market value management is extensive, and the system is relative complex, limited by personal level, time schedule and objective factors, lots of estimations in this paper are theoretical data. In the corresponding actual operations and market changes, these data might be deviated. And some problems still remain to be solved and 
perfected in the future.

\subsection{Expectations of the Study}

In the current market of our country, there are many disadvantages remaining to be solved. For example, indeed, many plans of market value management of domestic listed companies center on the short-term corporate share price, and these plans lack in optimization of long-term inner factors of the companies, such as corporate governance, management, investor relations, etc.

In the future, the mode of "listed companies + PE" will turn into the focus of market value management. It is a mode which introduces PE as strategic investor to set up buyout fund together. On the whole, the investment mode of "PE + listed companies" is a means of market innovation, which can have complementary advantages. It is helpful to stimulate the market vigor. Thus, it should be respected and approved.

\section{Acknowledgments}

While remaining responsible for any errors in this paper, the authors would like to thank guidance and advice of Dr. Yanjun Xv on choosing topics. We are also particularly grateful to "College students innovation and Entrepreneurship Project" program of Jinan University. Thanks Zhen Du and Shiqi Yu for their personal assistance in manuscript preparation.

\section{References}

Budde, J. (2007). Performance Measure Congruity and the Balanced Scorecard. Journal of Accounting Research, 45(3), 515-539. http://dx.doi.org/10.1111/j.1475-679x.2007.00246.x

Duyck, J. (1998). Value Based Management: Developing a Systematic Approach to Creating Shareholder Value. Academy of Management Perspectives, 12(2), 102-104. http://dx.doi.org/10.5465/ame.1998.650525

Guangyao, S., Guofang, L., \& Yanjun, L. (2008). Evaluation of the Market Value Management in Chinese Listed $\begin{array}{lllll}\text { Companies. } & \text { Chinese Journal of }\end{array}$ http://dx.doi.org/10.3969/j.issn.1672-884X.2008.01.014

HuaLin, W. (2007). Research on the Market Value Management of Listed Companies in China. Economic Herald, 11, 37-38. http://dx.doi.org/10.3969/j.issn.1004-8669.2007.11.012

Lueg, R. (2010). Shareholder Value und Value-based Management (VBM). Controlling, 22(6), 337-344. http://dx.doi.org/10.15358/0935-0381-2010-6-337

Martynova, V. S. (2014). Capital Structure Impact on Market Value of Merging Companies. Effective Crisis Management, (5), 102. http://dx.doi.org/10.17747/2078-8886-2011-5-102-105

Song, L. (2003). Comments on the Theoretical Evolution of the Western Capital Structure and Its E. Academic Exchange, 4, 54-58. http://dx.doi.org/10.3969/j.issn.1000-8284.2003.04.014

The British Standards Institution. (2004). Value management, value analysis, functional analysis vocabulary. http://dx.doi.org/10.3403/03107297

Weissenrieder, F. (n. d.). Value Based Management: Economic Value Added or Cash Value Added? SSRN Journal. http://dx.doi.org/10.2139/ssrn.156288

Yan, C. (2007). The development of value theory: Retrospect and Prospect. Communication of Finance and Accounting, 3, 78-81. http://dx.doi.org/10.16144/j.cnki.issn1002-8072.2007.03.036

\section{Copyrights}

Copyright for this article is retained by the author(s), with first publication rights granted to the journal.

This is an open-access article distributed under the terms and conditions of the Creative Commons Attribution license (http://creativecommons.org/licenses/by/4.0/). 